\title{
Age-Related Needs of Community College Students
}

\author{
L.E. DEVLIN* and P. GALLAGHER†
}

\begin{abstract}
The literature of adult education commonly suggests that older learners have a distinct set of needs and a unique mode of learning that ought to be honoured by educational institutions; other observers note that education is a process whose generic elements are not age-related. Capilano College, with a strong commitment to mature learners as part of its community orientation, surveyed its student population by age grouping to determine the extent to which significant, substantive differences in the self-perceived needs of different age groupings were evident. The survey revealed that, although there were several distinguishing characteristics between students below and above age 25 , younger and older students share a large common set of needs; older students seem to have a greater number of needs and appear to feel them more acutely.
\end{abstract}

\section{RÉSUMÉ}

Généralement, la documentation sur l'éducation permanente semble indiquer que les étudiants adultes éprouvent des besoins distincts et possèdent un mode d'apprentissage qui leur est particulier et dont les institutions d'enseignement devraient tenir compte. D'autres observateurs remarquent que l'instruction est un processus dont les éléments génériques n'ont rien à voir avec le facteur-âge. Le Collège Capilano dans la poursuite de son engagement envers les étudiants adultes et envers la communauté qu'il dessert a fait une étude de sa population étudiante par groupe d'âge afin de déterminer dans quelle mesure il y avait évidence de différences significatives dans les besoins perçus par les différents groupes d'âges. L'étude a révélé que malgré certaines caractéristiques particulières aux étudiants de moins et de plus de 25 ans, la population étudiante en général éprouve des besoins communs. Les étudiants adultes paraissent éprouver un plus grand nombre de besoins et semblent les ressentir plus vivement.

*Program Development and Evaluation, University Extension, University of Victoria.

$\dagger$ Capilano College, North Vancouver 


\section{INTRODUCTION}

Mature students have long been recognized as a significant, if not the priority, client group of the colleges and other non-degree granting post-secondary institutions which have been established throughout Canada in the last fifteen years. Indeed, responding to the needs of both conventional age college students and large numbers of more mature students has been identified as one of the more difficult challenges facing these institutions (Denis and Lipkin, 1972).

Some colleges have functioned as though the more mature student did not exist - or at least had to fend for himself in an environment designed for younger students. Other institutions have seen the more mature student as so different that they have provided special classes and services for older learners and, in effect, have operated two colleges under a single roof.

One college which claimed a special concern for more mature learners and viewed with skepticism much of the literature of adult education attempted to examine the extent to which the needs of their older students differed from those of conventional age college students. The results of that examination suggest that the integration of younger and older students in the college environment is largely beneficial to both student groups and to the college.

\section{THE CONTEXT}

Capilano College, one of British Columbia's 15 community colleges, was established in 1968 with the intention of becoming a true "college of its community". One of the earliest manifestations of its community orientation was its decision to treat all applicants alike - male or female, younger or older, part-time or fulltime, urban or suburban or rural. The first policies and practices of the college attempted to translate this democratic mission into reality: there was to be a single timetable with no separation into a day program for full-time students and an evening division for part-time students; there was to be no tuition fee differential, with part-time students being assessed on a pro rata basis; applicants were to be encouraged to take credit courses on an audit basis in preference to the college establishing credit free courses; services for students were to be offered in offhours as well as during conventional hours so that they would be equally accessible to working students, single parents and others for whom conventional college hours might be inconvenient.

An essential feature of the same strategy was that younger students - fresh secondary school graduates and those who wished a short breather after high school before tackling the rigours of college life - should learn side by side in the same classroom and laboratories with the great variety of older students citizens in their mid-twenties returning to formal education, women who wished to continue their education or acquire new skills after interruption of schooling or employment for child-rearing, older workers who wished to acquire new knowledge or skills, senior citizens who wished to avail themselves of learning opportunities not previously accessible to them. 
This approach to community-based educational opportunity became part of the operational fabric of Capilano College from its first year of operation. By 1979 , when the college had grown to more than 4,000 students on several campuses, this approach to older learners had become firmly imbedded in the culture of that college to the extent that the College Calendar proudly claimed:

We believe it is our blend of full-time and part-time, younger and older women and men that gives Capilano a special character and a special strength.

As part of its process of institutional self-evaluation and development of a fiveyear educational plan in 1980, and in response to external criticism of its untested assumptions about differences between younger and older students, the college established a faculty-administrative research Steering Committee and engaged the services of an external scholar to test its operating assumptions.

It was decided by the Steering Committee that Capilano students of different age groups should be surveyed to determine whether there were significant, substantive, unrecognized differences among them.

The rationale for this survey arose from the discrepancy between the Capilano approach to older students and the literature of adult education which often suggested that the older learner has both a unique learning style and a distinct set of needs which should be accommodated in educational practice (Brundage and MacKeracher, 1980). Some writers have employed the term andragogy to distinguish between the education of adults and that of children and youth which they class as pedagogy. The Capilano approach to older learners was more in line with other observers who see education as a process whose generic elements differ little, regardless of the age at which it is pursued.

The Capilano survey was intended to test this discrepancy as it applied to students in the broad range of programs offered by the college and to provide a context within which questions of educational philosophy and practice could be examined.

\section{THE SURVEY INSTRUMENT AND METHODOLOGY}

Rather than design a new instrument, the research Steering Committee decided to modify a questionnaire - The Survey of Student Needs Questionnaire - first developed by the two-year College Development Centre, State University of New York at Albany as part of a project to study adults returning to two-year colleges after a break in their formal studies (Mangano and Corrodo, 1978). The New York study had isolated findings of special value to New York college personnel and had led to a system-wide colloquium on these findings; Capilano personnel were interested in determining if the findings would be repeated in their setting, and so the questionnaire was adjusted merely to particular academic and administrative practices at Capilano College.

The Capilano survey contained 13 preliminary questions related to demogra- 
phic and other contextual variables followed by 77 scale items grouped into 5 general facets reflecting different dimensions of the collegiate experience (or 5 general categories of student need). These facets were:

a) Academic Survival Skills - basic tools of academic competence (9 items).

b) Personal/Social Development - those skills generalizable to a wide variety of situations not typically regarded as curriculum determinants (20 items).

c) Instructional Patterns - instructional policies, practices and attitudes that affect students' academic performance (21 items).

d) Administrative Policies - administrative procedures that establish the institutional context (13 items).

e) Student Support Services - institutional services that support and enhance the student's educational experience ( 14 items).

After pre-testing, the Capilano survey was administered in the Spring term 1981 to a systematic sample of classes proportional to enrolment in the three Instructional Divisions of the college: Academic Studies (university transfer and general education), Career Studies (two-year post-secondary employment-related), and Vocational (less than one-year employment skill training and basic education). A total of 72 classes were surveyed, resulting in a useable return of 711 questionnaires.

\section{CHARACTERISTICS OF RESPONDENTS}

The sampling method resulted in a respondent group which was similar to the college population as a whole on variables of particular interest to the study such as sex, age, full- or part-time status and area of academic study. Respondents were primarily female $(65.5 \%)$, age $15-24(65 \%)$ and full-time students $(66.6 \%)$. A total of $41.9 \%$ were registered in the Academic Division, $40.6 \%$ in Career Studies, and $14.9 \%$ in the Vocational Division. The largest number of respondents attended day classes only (62.9\%), $8 \%$ evening only and $29.1 \%$ both day and evening. Although a majority of students $(52.9 \%)$ had taken a high school or college course in the year previous to the study, $48 \%$ had been away from formal studies for at least one year including $23 \%$ who had been away for more than 5 years. A total of 247 were age 25 or older and 464 were age 24 or younger.

\section{ANALYSIS OF DATA}

In order to identify whether there were specific needs that were particular to a given age group, respondents were divided into two groups: Younger College Students (YCS), age 24 and younger, $(\mathrm{N}=464)$, and Older College Students (OCS), ages 25 or over, $(\mathrm{N}=247)$.

The mean score of each questionnaire item, as well as a grand mean and 
FIGURE I

ITEM CLASSIFICATION BY ORDER

Third Order

Second Order

First Order

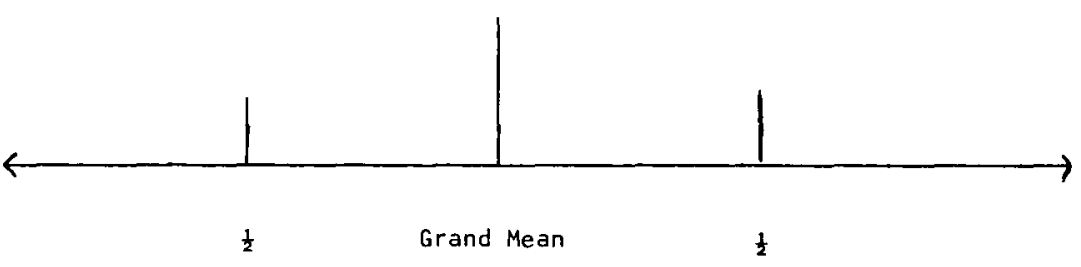

standard deviation, were computed for each group. Individual items with means that fell above one-half of one standard deviation above the grand mean for each group were described as First Order (highest priority) for that group. Items which fell below one-half of one standard deviation below the grand mean were described as Third Order (lowest priority). Those falling between these two points were described as Second Order (middle priority). Figure 1 illustrates the method used to classify specific items for each group.

This method of classification resulted in a Typology of Needs for each age group.

\section{RESULTS}

The primary concern of the study was with the question "Do older learners have needs which are different from those of younger learners at Capilano? "A comparison of items in each facet indicates what the survey revealed.

\section{Academic Survival Skills}

While both age groups identified "improving my study skills" as a First Order (priority) item, Older College Students also identified "learning how to prepare better term papers" and "improving my test taking skills" as First Order items. Thus 2 of 9 items in this facet distinguished between the age groups.

\section{Personal-Social Development}

Older College Students ranked "improving my motivation for college work" as a First Order item whereas this item fell into the Second Order for the group age 24 and younger. The item "getting together after class" was seen as more important to Older College Students (Second Order) than by the younger group (Third Order). Conversely, "a wide age range of students in my class" was a Third Order item for Older College Students and a Second Order item for the younger group. A total of 3 items in this facet thus distinguished between age groups. In two cases, the items were ranked higher by Older College Students, and, in one case, ranked lower. 
TABLE 1

TYPOLOGY OF NEEDS (Age $=24$ and younger)

\begin{tabular}{|c|c|c|c|c|}
\hline Domarn & FACET & $\begin{array}{l}\text { NEED CONTINCUUM } \\
\text { " First Order }\end{array}$ & Second Order & Third order \\
\hline \multirow[t]{2}{*}{ Learner } & $\begin{array}{l}\text { Acsdemic } \\
\text { Survival } \\
\text { Skills } \\
\text { *M }=3.35 \\
\text { SD }=.27\end{array}$ & 8. study ski11s & $\begin{array}{l}\text { 15. prepare papers } \\
\text { 25. note-taking } \\
\text { 38. writing skills } \\
\text { 45. vocabulary akills } \\
\text { 53. reading okills } \\
\text { 55. test-taking skills } \\
\text { 60. library facilities }\end{array}$ & 59. nath okille \\
\hline & $\begin{array}{l}\text { Personal- } \\
\text { Sorial } \\
\text { Development } \\
M=3.34 \\
\text { SD }=.52\end{array}$ & 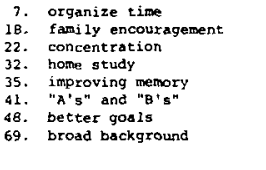 & $\begin{array}{l}\text { 20. working with students } \\
21 . \text { working alone } \\
24 . \text { fitting-in } \\
27 . \text { cope with failure } \\
\text { 39. keeping up } \\
\text { 49. notivation } \\
67 . \text { self confidence } \\
\text { 76. aesthetic stimulation } \\
\text { 77. wide age-range }\end{array}$ & $\begin{array}{l}\text { 50. reducing uneasiness } \\
51 . \text { students own age } \\
64 \text {. together after class }\end{array}$ \\
\hline \multirow[t]{3}{*}{ Provider } & $\begin{array}{l}\text { Instructional } \\
\text { Patterns } \\
\begin{array}{l}M=3.55 \\
S D=.62\end{array}\end{array}$ & $\begin{array}{l}\text { 4. interested instructors } \\
\text { 5. a-v materials } \\
\text { 12. realistic instructors } \\
28 . \text { more than one way } \\
30 . \text { modify ovtline } \\
\text { 33. inforths instructors } \\
46 . \text { instructor encouragement } \\
56 . \text { organize and develop } \\
61 . \text { instead of on tests } \\
71 . \text { course objectives } \\
73 . \text { intellectual curiosity } \\
74 . \text { comprehension } \\
75 \text {. language \& methodology }\end{array}$ & $\begin{array}{l}\text { 29. re-tests } \\
43 . \text { class discugsions } \\
68 . \text { how I'm doing } \\
72 \text { many gource materials }\end{array}$ & $\begin{array}{l}\text { 26. presentation in class } \\
42 \text {. students decide } \\
52 \text {. follow outline } \\
63 \text {. instructor lectures }\end{array}$ \\
\hline & $\begin{array}{l}\text { Adninistrative } \\
\text { Policies } \\
P=2.86 \\
S D=.64\end{array}$ & 19. skills useful on job & $\begin{array}{l}\text { 9. evening classes } \\
\text { 10. drop a course } \\
13 . \text { variety before major } \\
31 . \text { 1 } 1 \text { - or } 2 \text {-hour classes } \\
47 . \text { sumer classes }\end{array}$ & $\begin{array}{l}\text { 3. independent study } \\
11 . \text { evening classes } \\
\text { 36. 1-hour classes } \\
\text { 37. weekend classes } \\
\text { 40. off-campus courses } \\
62 . \text { class attendance } \\
66 . \text { 3-hour classes }\end{array}$ \\
\hline & $\begin{array}{l}\text { Student } \\
\text { Support } \\
\text { Services } \\
M=2.97 \\
\text { SD }=.38\end{array}$ & & $\begin{array}{l}\text { 1. campua study } \\
\text { 6. registex by mail } \\
\text { 17. occupational courselling } \\
23 . \text { financial aid } \\
34 . \text { register after } \\
54 . \text { placement services } \\
58 \text { academic counselling } \\
65 . \text { snack bar }\end{array}$ & $\begin{array}{l}\text { 2. bus service } \\
14 \text {. campus tour } \\
16 . \text { tutor } \\
44 \text {. child care } \\
57 . \text { campus activities } \\
\text { 70. personal counselling }\end{array}$ \\
\hline
\end{tabular}

- $M=$ mear of continuum theans for facet SD = standard deviation of continuus means for facet.

\begin{abstract}
- First order: continulum mear is more than 4 SD above the overall mean of contiriuum means. continuum mean is vithin i SD of overall mean of continuum means. continuum mean is more than 4 SD below the overall mean of cont inuum means.
\end{abstract}

\section{Instructional Patterns}

The item "being able to take 're-tests' to improve my grade" was a First Order item for Older College Students and a Second Order item for the age group 15-24. Younger students ranked two items more highly than Older College Students: "course objectives to guide my study" and "learning the language and methodology of a discipline". (First Order vs Second Order). Three items thus distinguished between groups.

\section{Administrative Policies}

The item "being able to take a variety of courses before deciding on a major field of study" was ranked more highly by Older College Students (First Order) than by students in the younger group (Second Order) as was the item "flexible 
TABLE 2

TYPOLOGY OF NEEDS (Age $=25+$ )

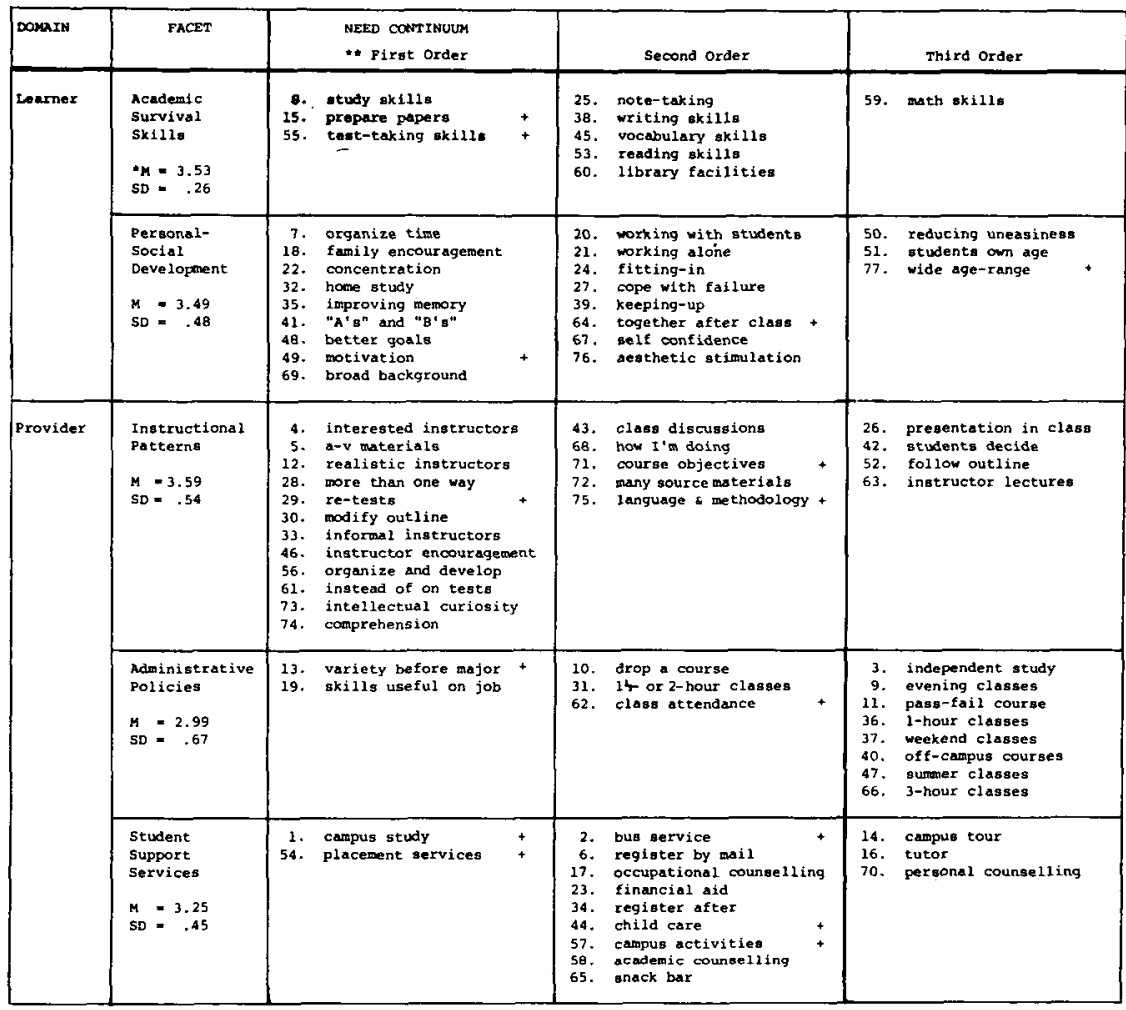

- $M$ - mean of continuum peang for facet

SD - standard deviation of continulim means for facet

\footnotetext{
*Firat Order: cont 1 nuum mean is more than 450 above the overall mean of continuum means. cantinuum mean is within 5 SD of overall mean

Second Order: cont inuum mean is within 3 SD of overall mean
Th1rd Order: continum means.
ont 1 numum man is more than 4 SD below the
overall mean of continum meang.

Second Order: cont inuum mean is within 3 SD of overall mean
Th1rd Order: continum means.
ont 1 numum man is more than 4 SD below the
overall mean of continum meang.

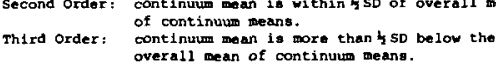
+ Items wich sppear in a different cell on the age - 24 and younger table.
}

requirements for class attendance" (Second Order vs Third Order). Two items "evening classes" and "summer classes" - were ranked more important by age group 24 and younger (Second Order) than by Older College Students (Third Order). Four items thus distinguished between groups.

\section{Student Support Services}

Older College Students ranked two items as First Order - "a good place to study on campus" and "job placement services" - whereas these items fell in the Second Order for the younger age group. Older College Students ranked three additional items more highly than did the younger age group (Second Order vs Third Order) - "bus service to the campus", "campus activities for students 
with interests similar to mine", and "child care facilities on or close to campus". A total of 5 items thus distinguished between groups.

In summary, the following 12 items were ranked more highly by Older College Students (age 25+) than by Younger College Students (age 24 and younger). First Order (Priority) items are noted with*.

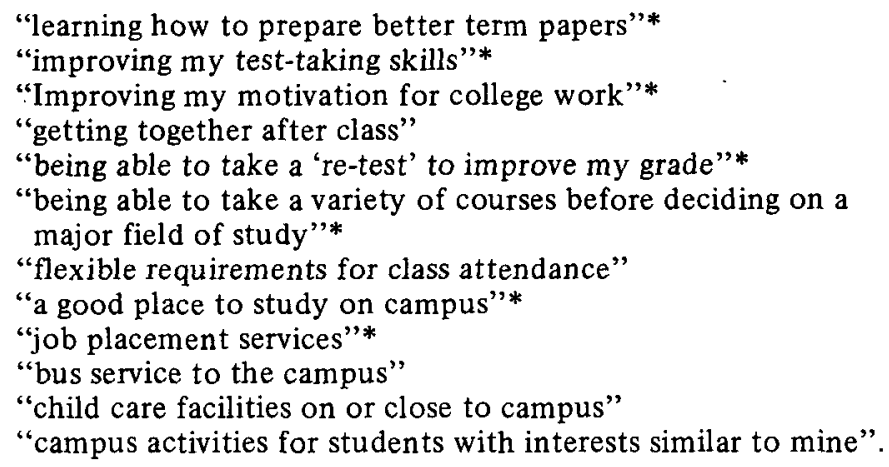

The following 5 items were ranked more highly by Younger College Students than by Older College Students. None were First Order items.

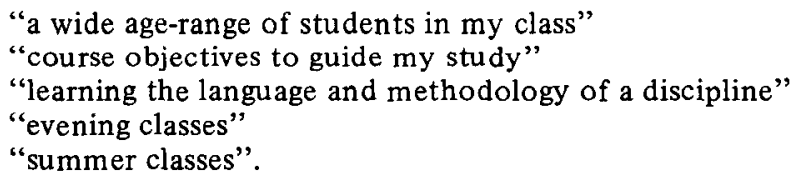

\section{DISCUSSION OF RESULTS}

The specific objective of the study was to determine whether there are significant, substantive differences which can be identified as primarily age-related in the self-perceived needs of students in college.

While 17 items were distinguished between the two age groups, the remaining 60 were given the same ranking - i.e. First, Second or Third Order - by both groups. It is thus clear that both older and younger students have a large, common set of needs. Older students, however, appear to have a modestly greater number of needs than do younger students, as illustrated by the finding that older students ranked 28 needs as First Order while younger students identified 23 such needs. There is also some evidence to suggest that older students "feel" their needs more acutely. Of 12 specific needs ranked more highly by older students than by younger students, 7 were First Order.

Some specific needs identified by older students appear to be a logical characteristic of learners who begin or return to post-secondary study after an interrupted formal education. For example "learning how to prepare better term papers" and "improving test-taking skills" are types of needs which would appear 
to flow from the adult status of older learners. Despite this finding, older learners identified some First Order (priority) needs which are not predictable on an age basis. Although it is generally believed that older students are more purposeful when they return to formal studies, older learners in this study ranked "being able to take a variety of courses before deciding on a major field of study" as an important need. Similarly, the need to "improve my motivation for college work" was a First Order need in the current study. Conventional wisdom might ascribe this need to the younger learner.

Considered as a group, the results do not provide unequivocal support for the belief that older and younger students have markedly different sets of needs. Nevertheless, seventeen items did distinguish between the two age groups.

\section{FOR FURTHER STUDY}

For Capilano College, the results of this survey tend to support the claim that its approach to more mature learners is valid and that, at worst, minor operational adjustments might be necessary to accommodate the needs of both younger and older college students. Special attention to the distinctive First Order needs identified by older students seems in order.

The survey is, however, hardly conclusive or indicative of the priority of needs of more mature students that might be evident in other colleges. It would be instructive to conduct the same survey in other colleges and to determine the extent to which the results at one college are repeated elsewhere.

Similarly, the value of the survey is limited by the fact that it does not reveal reasons why the needs of older and younger adults appear so common. It may be that the commonality of need identified at Capilano College is the product of a concerted and continuing effort by the personnel of that college to be sensitive to older students to a degree not characteristic of other colleges. It may be that Capilano College instructors have uniquely developed approaches to teaching younger and older students together that account for results at that college which would not be evident elsewhere.

It is also clear that the survey merely identifies the self-perceived needs of students; it does not reveal the extent to which the college satisfies any of these needs, and this is a far more critical operational issue for any institution. That issue has since been addressed at Capilano College by a different survey instrument.

Equally, the results of the survey distinguish self-perceived needs of only two groupings of students: those under age 25 and those 25 and older. Within the latter grouping, it may well be that students in their late 20 's, for example, have needs very different from students in their 50's or beyond. Fortunately, the results were collected separately for several discrete age groups beyond age 24 and it is possible to compare results of students in each of these age groups. Similarly, the results for male and female students in all age groups can be scrutinized more closely although the initial analysis of results does not suggest significant differences by gender. 
The college's expedient decision to use a survey instrument designed for the study of adults in the New York college system, rather than to develop its own instrument, appears sound in terms of the objective of the study; there is no reason to believe that the differences between New York and North Vancouver students or educational environments are so marked as to render the instrument invalid for the Capilano setting. The purpose of the instrument was to identify similarities and differences of need by age, and it did that.

Capilano College has claimed, however, not merely that differences in needs of students are not primarily a factor of age; the college also suggests that there is an educationally symbiotic relationship between younger and older college students. The survey did not address this relationship and, to that extent, at least some aspects of the Capilano College approach to older students still remain in question.

\section{REFERENCES}

Brundage, D. \& MacKeracher, D. Adult Learning Principles and Their Application to Program Planning. Toronto: Ontario Ministry of Education, 1980.

Denis, A. \& Lipkin, J. Quebec's Cegep: Promise and Reality. Mc Gill Journal of Education, 1972, 7 (2), 119-134.

Knowles, M. The Modern Practice of Adult Education: Andragogy vs. Pedagogy. Chicago: Association Press Follet Publishing Company, 1970.

Mangano, J.A. \& Corrodo, T.J. Meeting Academic Success Needs of Re-entry Adults. Albany, New York: Two-year College Development Center, State University of New York, 1978. 